Edubiotik: Jurnal Pendidikan, Biologi dan Terapan
ISSN 2528-679X (print), ISSN 2597-9833 (online)
Vol. 6, No. 01, February 2021, pp. $9-16$
Available online at:
http://ejurnal.budiutomomalang.ac.id/index.php/edubiotik

\title{
Research Article \\ Creating miniature ecosystem to increase student learning outcomes through guided discovery learning
}

\author{
Fatikhatun Nikmatus Sholihah ${ }^{1 *}$, Suci Prihatiningtyas ${ }^{2}$ \\ ${ }^{1}$ Biology Education, K.H. A. Wahab Hasbullah University, Jombang, Indonesia \\ 2Physics Education, K.H. A. Wahab Hasbullah University, Jombang, Indonesia \\ Email: faiha.achmad@unwaha.ac.id*, suciningtyas@unwaha.ac.id
}

\begin{tabular}{ll}
\hline Article Information & \multicolumn{1}{c}{ ABSTRACT } \\
\hline Submitted: 2021-01-04 & Basic ecology is the basic science that studies the interrelationships between \\
Accepted: 2021-03-17 & living things and their environment. One of the content in this course is terrestrial \\
Published: 2021-04-30 & ecosystems. The aim of learning this subject is students can carry out \\
& experiments (practicum) both in the laboratory or in the UNWAHA environment. \\
& This research aims to improve the cognitive learning outcomes of students by \\
applying guide discovery learning in making miniature ecosystems. This research \\
uses a pra experiment design. This research uses a one-group pretest-posttest \\
design research design that is doing a pre-test before implementation and a post- \\
test after implementation. To know the increase of student's cognitive learning \\
outcomes through guide discovery learning, used N-gain test and paired sample t- \\
test. The research instruments used are observation sheets and tests (pre-test \\
and post-test). The results showed that the cognitive learning outcomes of \\
students increased with an average grade of 64 to 84 . N-Gain results show that \\
two students of low category, 16 students of moderate category, and three \\
students of high category students. Based on the results of the t-test obtained Sig \\
<0.05 is 0.00. Then it can be stated that there is a significant difference between \\
the value of pre-test and post-test. In other words, there was an increase in \\
student learning outcomes after the implementation of discovery learning guide \\
learning. Based on the average class and t-test results, concluded that guided \\
discovery learning can increase student's cognitive learning outcomes.
\end{tabular}

\section{INTRODUCTION}

The ecosystem is the merging of each unit of the biosystem involving reciprocal interactions between organisms and the environment so that there is a cycle of matter between organic and 
inorganic (Djunaid \& Setiawati, 2013). Ecosystems are also systems of reciprocal relationships between biotic components and abiotic components that affect them. Ecosystems are inseparable from various other ecological functions such as the $\mathrm{O}_{2}$ cycle, the creator of the microclimate, and the absorption of groundwater (Besila \& Kusumadewi, 2016). In other words, ecosystems are a whole and comprehensive unity order between all elements of the environment that affect each other. It is not easy to study the whole unity order and affect each other especially ecosystems outside our environment. The terrestrial ecosystem (land) is one type of ecosystem in our environment.

Terrestrial ecosystems are one of the materials in basic ecology courses at $\mathrm{KH} \mathrm{A}$. Wahab Hasbullah University (UNWAHA). One ofthe the objectives of this course is that students can carry out experiments (practicum) either in the laboratory or in the UNWAHA environment. Based on an interview with the lecturer of basic ecology at UNWAHA, the media used to study the types of terrestrial ecosystems limited to using images and videos sourced from youtube. A learning media is needed that can represent the type of ecosystem, namely miniature ecosystem (Crysty et al., 2017). Miniature ecosystems are imitations of ecosystems on a small scale to visualize complex ecological materials. The creation of miniature ecosystems makes learning fun and students enjoy making miniatures because it sharpens creativity (Setyaningrum et al., 2015). Student creativeness is proven by the results of miniature products of a good and interesting ecosystem by using tools/materials that are around us. Susilawati et al. (2016) also explained that meaningful learning in practice will familiarize students to do research, observation, experiments, observation, and information gathering activities from various sources. Based on the description, the manufacture of the terrarium needed guidance but still bring up concepts from students, one of which guide discovery learning.

Guide discovery learning is learning based on discovery or inquiry-based, constructivist, and theory of how to learn. This learning can train students to solve a problem. An easy-to-observe problem in this learning is the understanding of concepts (cognitive) about the material components of the ecosystem. Problem-solving can be done by conducting experiments through their design. A method that provides opportunities for students to have scenarios or ways to solve real problems and encourage them to solve their problems (Syarofah et al., 2019). This opinion is similar to Wahyuni (2017) that guides discovery learning is constructivist so that students use their previous experience in solving problems by interacting to explore, questioning during experimentation with trial and error techniques. Constructivism was also revealed by Kouriourouki (2020), in his research on project learning which states that the most important factors to stimulate student interest are using examples, arguing/communication, as well as utilizing audiovisual media. Based on the explanation above, it is expected that there was an increase in student learning outcomes after the implementation of discovery learning guide learning. So, this research aims to improve the cognitive learning outcomes of students by applying guide discovery learning in making miniature ecosystems.

\section{RESEARCH METHODS}

This research is an experimental pra research that uses only one class of data retrieval. This research uses the research design of one group pretest-posttest design that is done pretest before the implementation of guide discovery learning so that the implementation results can be known more accurately by comparing the circumstances before and after treatment (Sugiyono, 2010). This is the one-group pretest-posttest design is used in this research.

\section{$01 \times 02$}


Description:

$01=$ pretest (before implementation of guide discovery learning)

$\mathrm{X}=$ treatment with the implementation of guide discovery learning

$\mathrm{O} 2$ = posttest (after implementation of guide discovery learning)

The research place is carried out in each student's home. The research was conducted on May 5 - May 12, 2020, with 21 students. The subject of this research was students who obtained low cognitive learning outcomes and had never created a miniature ecosystem. This research procedure covers two stages, namely the preparation and implementation stages. Before data collection, researchers conducted observations in the form of interviews with lecturers who have basic ecology courses. Interviews were also conducted with students of Biology Education UNWAHA who had received basic ecological courses. The preparation stage was carried out before the government's appeal about the COVID-19 disaster. There are two meetings in guide discovery learning. The first meeting begins with a pretest. Pretest used google form pretest. Then continued stimulation in the form of a video about biome (stimulation/provision of stimuli), problem statement (identification of problems) using miniature ecosystem student worksheet data collection by determining the tools of materials for making miniature ecosystems, data processing is carried out as a task at home by providing video tutorials on making miniature ecosystems by researchers. The last meeting is verification by showing the results of miniature ecosystem by students, generalization (generalization/drawing conclusions), evaluation process (sixth synth), and posttest using google form.

The research instruments used are observation sheets and tests. The observation sheet used is the interview sheet. The interview was conducted with students of Biology Education UNWAHA who had studied Basic Ecology. The test is used to know students' cognitive learning results. The test is a double-choice question of 20 questions. Research data analysis techniques using quantitative analysis. Determine the cognitive learning outcomes of 21 students individually can be calculated by using the following formula (Prihatiningtyas et al., 2020).

$$
\text { Individual Assesment }=\frac{\text { The number of indicators achieved }}{\text { the number of all indicators }} \times 100
$$

To find out the difference between the pretest and posttest mean values, you should use the NGain/Hake formula (Meltzer, 2002) and categories of acquisition of N-Gain value that can be seen in Table 1.

$$
\mathrm{N}-\text { Gain }=\frac{\text { post test value }- \text { pre test value }}{\text { maximum value }- \text { pre test value }}
$$

Table 1. Categories of Acquisition of N-Gain Value

\begin{tabular}{cc}
\hline Limit & Category \\
\hline$g>0.7$ & High \\
$0,3<g \leq 0.7$ & Moderate \\
$\mathrm{g} \leq 0.3$ & Low \\
\hline
\end{tabular}

After the value of each test is known, it is done paired sample t-test through the SPSS program (Fauziyah, 2016). The use of paired-sample t-test to find out the difference in pretest and posttest values. Paired t-test is one of the hypothetical testing methods where the data used is not free (paired). Researchers obtained two kinds of sample data, namely data from the first treatment or pretest and 
data from the second treatment or posttest (Montolalu \& Langi, 2018). Basic decision making, if sig < 0.05 then there is a significant difference if the result of sig $>0.05$ then vice versa.

\section{FINDINGS AND DISCUSSION}

The results of students' cognitive learning can be seen from the value of pretest and posttest. Pretest value is the value before the implementation of guide discovery learning and posttest value is the value after the application of guide discovery learning. Students' cognitive learning outcomes are calculated individually. Analysis of students' cognitive learning results can be seen in Figure 1.

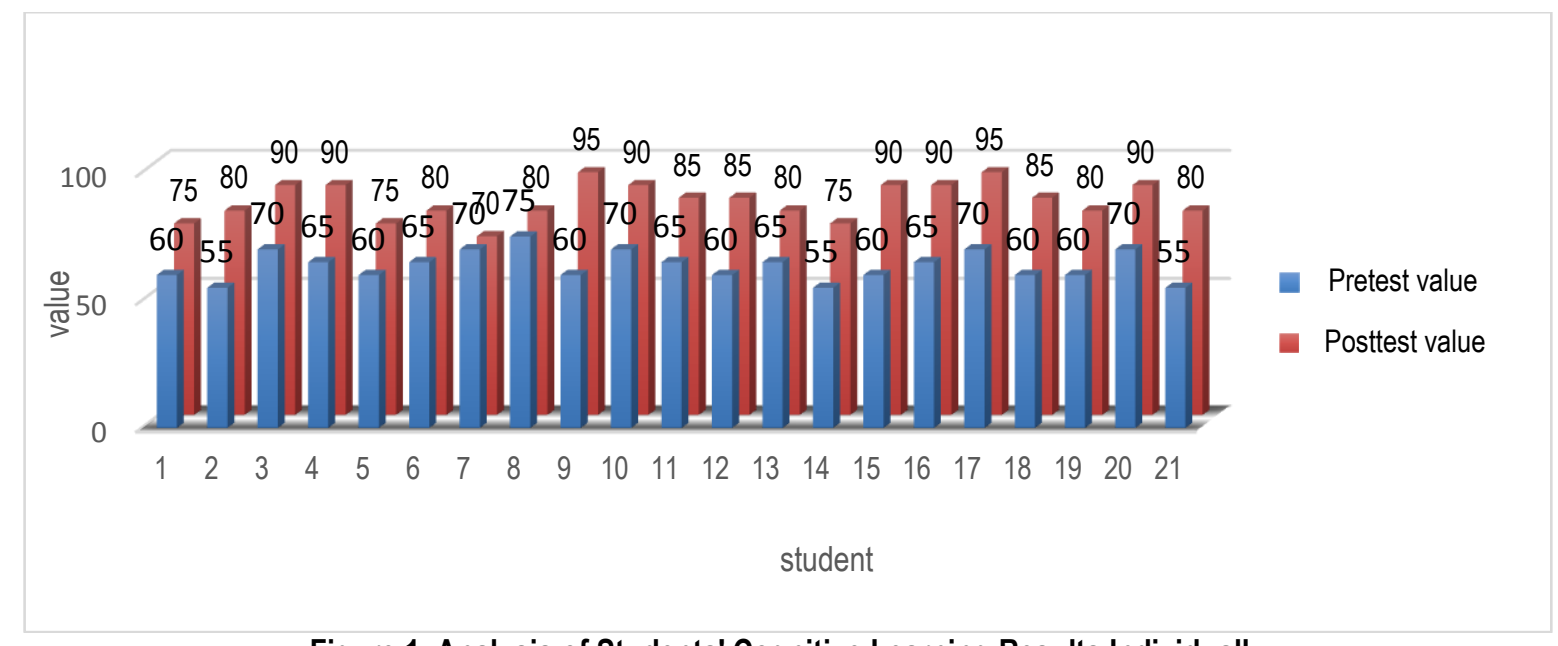

Figure 1. Analysis of Students' Cognitive Learning Results Individually

Based on Figure 1 shows that all of the students' cognitive learning outcomes increased by an average grade score of 64 to 84 . The value is obtained from the total value of students divided by the number of students. Of these, 15 students experienced 20 points, 5 students experienced 25-points, and one of them even 35 points from 60 to 95. This is by following with Wahyuni (2017) opinion that learning guides help students to improve and improve cognitive skills and processes. The results of cognitive learning can not be separated from the understanding of students when doing activities making miniature ecosystems. The activities of creating miniature ecosystems influence students to be actively involved in the learning process so that they understand the concept. Understanding the concept can be interpreted as the thought process of a person to process the received teaching materials so that it becomes meaningful (Seda \& Sundaygara, 2019). Meaningful teaching materials lie in the ingress of the tools and materials contained in them (Pangesti, 2012).

Based on the results of cognitive learning of students, it can be decided that there is a difference between the results of pretest and posttest using the N-Gain formula (Prihatiningtyas et al., 2020). Figure 2 shows an analysis of the $\mathrm{N}-\mathrm{G}$ ain result. Analysis of $\mathrm{N}-\mathrm{G}$ - ain result shows that $5 \%$ or two students of a low category ( $\mathrm{N}$-Gain scores of 0.2 ), $54 \%$ or 16 students of a moderate category ( $\mathrm{N}$-Gain scores of $0.4,0.5,0.6$, and 0.7 ), and $41 \%$ or three high category students with N-Gain values of 0.8 and 0.9. This indicates that there is a difference between the pretest and posttest results. Two students got low $\mathrm{N}$-gain grades due to a lack of material mastery of the ecosystem.

The results of pretest and postest are then hypothetical tested using paired sample t-test through the SPSS program. The basis of this decision-making, if sig $<0.05$ then there is a significant difference, if the result of sig $>0.05$ then vice versa. The following are the results of paired sample t-test using SPSS. Test results paired sample t-test can be seen in Table 2. 


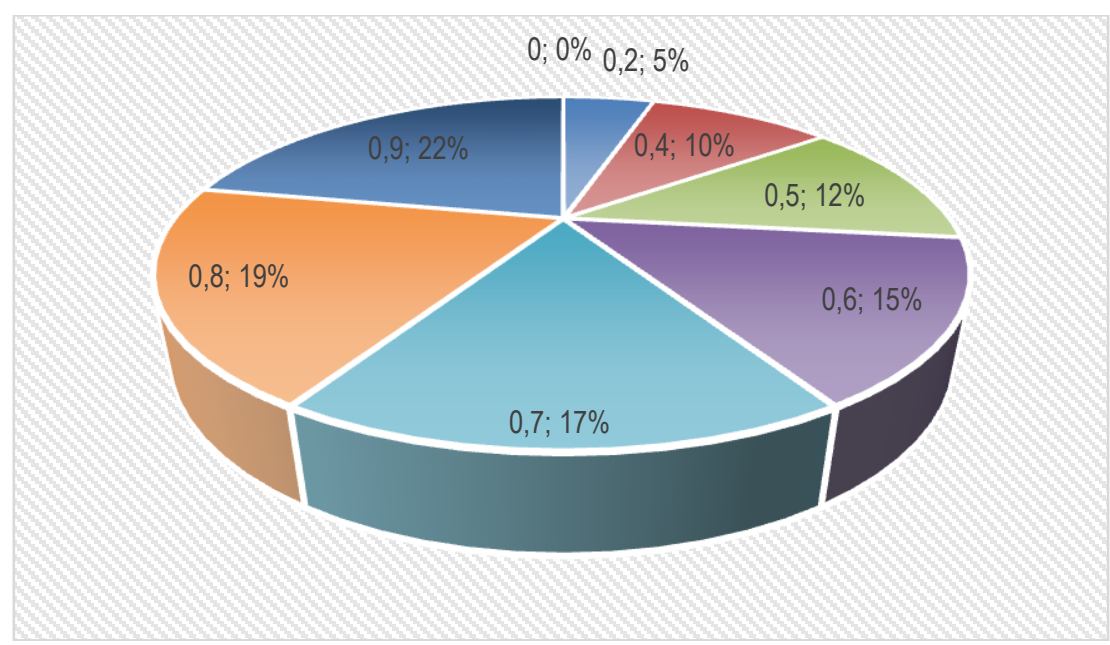

Figure 2. Analysis of N-Gain results

Table 2. Paired Sample t Test Results

\begin{tabular}{ccccccccc}
\hline Aspects & Average & $\begin{array}{c}\text { Standard } \\
\text { Deviation }\end{array}$ & $\begin{array}{c}\text { Average } \\
\text { Standard } \\
\text { Error }\end{array}$ & Bottom & $\begin{array}{c}\text { Top of } \\
\text { the }\end{array}$ & $\mathbf{t}$ & df & Sig. \\
\hline Pretes - postes & -20.23810 & 7.82243 & 1.70700 & -23.79882 & -16.67737 & -11.856 & 20 & .000 \\
\hline
\end{tabular}

Based on Table 2 obtained that sig $<0.05$ is 0.000 . So, it can be stated that there is a significant difference between the value of pretest and posttest. This difference can also mean that students' cognitive learning outcomes improve. Improved cognitive learning results show that students' understanding of terrestrial ecosystem materials is also increasing. The increasing cognitive learning results of students can not be separated from the creation of miniature ecosystems by determining the components of the ecosystem (the third stage of guide discovery learning), arranging components correctly (the fourth stage of guide discovery learning), and involving activeness and showing student creativity (the fifth stage of guide discovery learning).

The increasing results of student learning can not be separated from the learning model used especially in the third, fourth, and fifth stages. Sari et al. (2016) in the results of their research, wrote that discovery learning can involve the activeness of learners in learning ranging from observing biological phenomena to concluding independently so that the knowledge obtained is more meaningful. Similar to Syarofah et al. (2019), that this discovery learning model can be used to develop an interesting learning plan and have an impact on improving student learning outcomes. Miniature ecosystem Student Worksheet that has been applied to the discovery learning guide can help students determine the tools and materials used (third stage of guide discovery learning) and can guide students to create miniature ecosystems (the fourth stage of guide discovery learning). The use of a miniature ecosystem student worksheet not be separated from the guidance of a teacher. This guidance is needed to anticipate negative things such as cognitive overload, potential misunderstandings, and teacher's difficulties to detect problems and misunderstandings (Simamora et al., 2018). So the miniature ecosystem student worksheet is one of the guides when the implementation of guided discovery to improve student understanding.

These three opinions are supported by Setyaningrum et al. (2015), which explains that learning not only requires students to make direct observations in nature but also hones students' skills in making complex ecological materials easy to understand, among others, can be realized in the form of 
miniature ecosystems. Guided learning discovery enables students to build their knowledge through activities designed (Batubara, 2019). In this study e-learning is one of the ways of learning methods that are by following this pandemic period. Student skills can be seen in the video that has been made (the sixth stage of guide discovery learning) and easily observed the truth of the concept about the components of the ecosystem.

Wabula et al. (2020) explained in their research that the video-assisted discovery learning model also emphasizes problems and discoveries, but in this learning model, students do not invite lecturers to do discovery planning so that student skills are very visible in the results of miniature ecosystem videos. Skills learned in discovery learning situations in some cases, are easier to transfer for new activities and applied in new learning situations, in this case, e-learning, especially in the form of miniature ecosystems (Anjani \& Hamdani, 2018). Silahuddin (2015) said e-learning at this time can be used as one of the approaches in education and can also be a strategic media and active, creative, innovative learning methods in creating human beings who are knowledgeable and believe overcome global challenges and able to implement them in everyday life. The opinion is following with the results of research that the creation of a miniature ecosystem in addition to improving the cognitive learning outcomes of students, can also make students creative and innovative through the creation of miniature ecosystems. Miniature creation of this ecosystem can be one of the props that can be used by educators as a medium of ecosystem learning in the form of mini. The advantages of this miniature can be used in the classroom so that the presentation of this material can be received more easily by students (Sholihah et al., 2019).

\section{CONCLUSION}

The result of the research shows that students' cognitive learning outcomes increased with an average grade score of 64 to 84 . Based on t-test results sig $<0.05$ is 0.000 . So it can be stated that there is a significant difference between the value of pre-test and post-test. Based on the average class and t-test results, concluded that there is an increase in students' cognitive learning outcomes after the implementation of guide discovery learning.

\section{ACKNOWLEDMENT}

Thank you to Kemristekdikti for providing funds to our research grant program and also LPPM UNWAHA who has supported this grant research activity.

\section{REFERENCES}

Anjani, D., \& Hamdani, A. R. (2018). Penggunaan model discovery learning untuk meningkatkan hasil belajar siswa kelas IV pada subtema kebersamaan dalam keberagaman. Jurnal Pendidikan Guru Sekolah Dasar, IV, 243-278. https://doi.org/10.36989/didaktik.v4i2.74

Batubara, I. H. (2019). Improving student's critical thinking ability through guided discovery learning methods assisted by geogebra. International Journal For Educational And Vocational Studies, 1(2), 116-119. https://doi.org/10.29103/ijevs.v1i2.1371

Besila, Q. A., \& Kusumadewi, A. W. (2016). Penerapan konsep ekologis untuk pendidikan lingkungan pada "taman pintar" di kelurahan kayu putih, Jakarta Timur. 15, 775-782. Retrieved from https://jurnal.uns.ac.id/prosbi/article/view/33346

Crysty, V., Manurung, B., \& Syarifuddin. (2017). Pengembangan kegiatan mini-lab pada topik ekologi dan lingkungan untuk siswa kelas X SMA. Jurnal Pendidikan Biologi, 6(3), 376-380. https://doi. org/10.24114/jpb.v6i3.8045 
Djunaid, R., \& Setiawati, H. (2013). Gastropoda di perairan budidaya rumput laut (Eucheuma sp.) kecamatan Suppa kabupaten Pinrang. Bionature, 19(1), 35-46. https://doi.org/10.35580/bio nature.v19i1.5528

Fauziyah, R. (2016). Efektivitas penggunaan modul untuk meningkatkan hasil belajar mata pelajaran boga dasar kelas $X$ di SMK Negeri 1 Kalasan Yogyakarta. Retrieved from https:/leprints. uny.ac.id/40048/

Kouriourouki, M. (2020). Techniques for oral communication during project implementation among student-teachers-research. International Journal of Education and Research, 8, 63-74. Retrieved from https://www.jjern.com/journal/2020/February-2020/07.pdf

Meltzer, D. E. (2002). The relationship between mathematics preparation and conceptual learning gains in physics: A possible "hidden variable" in diagnostic pretest scores. American Journal of Physics, 70(12), 1259-1268. Retrieved from https://eric.ed.gov/?id=EJ658132

Montolalu, C. E. J. C., \& Langi, Y. A. R. (2018). Pengaruh pelatihan dasar komputer dan teknologi informasi bagi guru-guru dengan uji-t berpasangan (paired sample t-test). Jurnal Matematika dan Aplikasi Decartesian, 7, 44-46. https://doi.org/10.35799/dc.7.1.2018.20113

Pangesti, F. (2012). Pengembangan bahan ajar pendidikan berpikir (kritis dan kreatif) berbahasa indonesia sma melalui pembelajaran lintas mata pelajaran. Retrieved from http://karya-ilmiah. um.ac.id/index.php/sastra-indonesia/article/view/20102

Prihatiningtyas, S., Sholihah, F. N., \& Angga, P. I. (2020). Pemahaman konsep mahasiswa melalui lembar kegiatan mahasiswa berbasis project based learning pada materi momentum dan impuls. Prosiding Seminar Nasional Pembelajaran IPA Ke-5 "Membangun Generasi Unggul melalui Merdeka Belajar IPA di Era New Normal" ,45-52. Retrieved from http://ipa.fmipa.um.ac.id/ en/2021/01/prosiding-seminar-nasional-pembelajaran-ipa-ke-5-um-tahun-2020/

Sari, E. Novitasari, Ridlo, S., \& Utami, N. Rahayu. (2016). Pengaruh model pembelajaran discovery learning dengan mind mapping terhadap hasil belajar siswa pada materi sel di SMA. Usej: Unnes Science Education Journal, 5(3), 1403-1407. Retrieved from https://journal.unnes.ac.id/sju/index. php/usej/article/view/13171

Seda, E., Ain, N., \& Sundaygara, C. (2019). Pengaruh model pembelajaran discovery learning dengan menggunakan media video terhadap hasil belajar siswa. Jurnal Pendidikan (Teori dan Praktik), 4(1), 59. https://doi.org/10.26740/jp.v4n1.p59-62

Setyaningrum, Tri Wahyu., Rahayu, Enni Suwarni, \& Setiati, N. (2015). Pembelajaran berbasis proyek pembuatan miniatur ekosistem untuk mengoptimalkan hasil belajar ekologi pada siswa SMA. Unnes Journal of Biology Education, 4(3), 290-297. Retrieved from https://journal.unnes.ac.id/ sju/index.php/ujbe/article/view/9582

Sholihah, F. N., Wulandari, A., \& Qomariyah, U. K. N. (2019). Kreativitas guru TKIT Al Mishbah dalam pengembangan model pembelajaran lab mini melalui terrarium ekosistem. Jurnal Abdimas BSI: Jurnal Pengabdian Kepada Masyarakat, 2(2), 366-373. Retrieved from https://ejournal.bsi.ac.id/ ejurnal/index.php/abdimas/article/view/6116

Silahuddin, S. (2015). Penerapan e-learning dalam inovasi pendidikan. Circuit: Jurnal IImiah Pendidikan Teknik Elektro, 1(1), 48-59. Retrieved from https://jurnal.ar-raniry.ac.id/index.php/circuit/article/ view/310

Simamora, R. E., Saragih, S., \& Hasratuddin, H. (2018). Improving students' mathematical problem solving ability and self-efficacy through guided discovery learning in local culture context. International Electronic Journal Of Mathematics Education, 14(1), 61-72. Retrieved from https://www.iejme.com/download/improving-students-mathematical-problem-solving-ability-andself-efficacy-through-guided-discovery-3966.pdf

Sugiyono. (2010). Metode penelitian kuantitatif kualitatif dan R\&D. CV Alfabet.

Susilawati, E., Rahayuningsih, M., \& Ridlo, S. (2016). Pengembangan perangkat pembelajaran ekologi SMA dengan strategi outdoor learning. Unnes Science Education Journal, 5(1), 1091-1097. Retrieved from https://journal.unnes.ac.id/sju/index.php/usej/article/view/9568 
Syarofah, F., Wiryokusumo, I., \& Sugito. (2019). Penerapan metode discovery learning dan ekspositori terhadap peningkatan hasil belajar PKN siswa. 7(2), 222-226. Retrieved from https://journal. ipts.ac.id/index.php/ED/article/view/938/423

Wabula, M., Papilaya, P. M., \& Rumahlatu, D. (2020). Pengaruh model pembelajaran discovery learning berbantuan video dan problem based learning terhadap motivasi dan hasil belajar siswa. Edubiotik: Jurnal Pendidikan, Biologi dan Terapan, 5(01), 29-41. https://doi.org/10.33503/ ebio.v5i01.657

Wahyuni, D. (2017). Penerapan discovery learning untuk meningkatkan kemampuan membaca pemahaman siswa kelas VB SD Negeri 004 Bukit Datuk Kota Dumai tahun pelajaran 2015/2016. Jurnal Mitra Pendidikan, 1, 79-90. Retrieved from https://e-jurnalmitrapendidikan.com/index.php/ e-jmp/article/view/73/30 